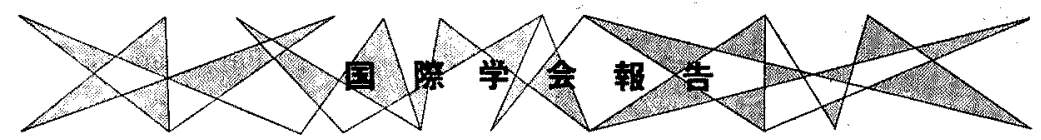

\section{永年作物の土壤と栄養に関する 国際会議に参加して}

前号に紹介した「第 4 回ヨーロッパ植物生理学会連合 会議」と同様に, 標題の国際会議夺㖘化誌 58 巻 7 号, 758〜765 頁の国際会議一覧には紹介されていないが， 土堙肥料学や植物栄着学に関する国際会議が農化誌儿紹 介されたことはこれまでほとんどないと思うので紹介す ることにした。

標題の国際会議 “International Conference on Soils and Nutrition of Perennial Crops" (以下 ICOSANP と記す)は, 1984 年 8 月 13 日〜15 日, アレーシア, クフラルン・プールのメルリン・ホテルで，マレーシフ 土瞔学会 (Malaysian Society of Soil Science) の組織 と運営の下に開かれた。、レーシア土壤学会は日本でい 兊济日本土壤肥料学会に相当し，肥料学や植物栄㙋学な どの研究者も含ま机ている，会員数は発足時 (1971 年) の 26 人から 1984 年 3 月現在では 370 人であるとい 万.創設は 1971 年 4 月という非常に若い学会である が, 1973 年以来, 毎年 1 ～ 2 回のシンボジウムや会議な どを開催し，1977 年の “Classification and Management of Tropical Soils" Ł 1981 年の "Potassium and Phosphorus in the Tropics” の2つの国際会議をすで に手がけて㧍り, 今回の ICOSANP はマレーシフ土堙 学会が組織，運営する3回目の国際会議であった。これ らのシンポジウムや国際会議の内容は常に proceedings として発行されており，今回のICOSANPに関する proceedings も発行される予定である.

さて会議の参加者は 213 名が登録されており，その内 訳はマレーシア (161 人), インドネシア (12人), タイ (5人), 台湾, スリランカ, オーストラリア (各 4 人), フィリピン, パプフ・ニューギニフ, 西ドイッ（各 3 人), シンガポール, 日本, 中国, イギリス（各 2 人）, フィージー島, ソロモン島, カナダ, ナィジェリア, オ ランダ、ベルギー（各1人）であった、マレーシアの参 加の多いのは当然としても，インドネシフ，タイ，スリ
ランカなどの参加に比べてインドの参加のなかったの は, この ICOSANP の前に “Oil palm” についての国際 会議があり，こちらの活らに参加していたためであると のことだそうである、日本からは筆者と酷農学園大学の 原田 勇先生の 2 人であった。

会議は 8 月 13 日， 7 時 30 分からの登録とそれに直 らに続く 8 洔 45 分からの開会式で始まった．この開 会式ではマレーシア農業省のY.B.Encik Anwar bin Ibrahim（以下すべて敬称略）と，本会議の組織委員長 でありマレーシア土锤学会会長でもある Dr. Mok Chak Kim の挨拶があったはずであるが，筆者はこれに参加 できなかったというのは，8月10日にスイスを立 ち、シンガポール経由で8月 12 日にはすでにクアラル ン・プールのスルリン・ホテルには着いていたが，7月 25 日のヨーロッパ出発時までに会議の案内状をもらう ことができず，開催時間など全く知らされていなかった ことと，初日の午前中はまず登録ぐらいと考えていたか らである。しかしな゙ら，開会式と 30 分の小休㽬後， 10 時 15 分から直ちに本会議の七ッションIに入った が、これには間に合った。

本会議はエからXまでのセッションが設けられ，3題 の keynote paper と 31 題の paper が報告された. 8 月 13 日は Nutrition [i ] [iv] に関するセッション $\mathrm{I} \sim \mathbb{N} て ゙ 1$ 題の keynote paper $と 12$ 題の paper が, 8月 14 日は Plant and environment [i ] [iv] に関 する七ッション V〜相で 1 題の keynote paper と 12 題の paper が, また 8 月 15 日は Fertilizer use and management practices [ i ] [ [ii] K関するセッシ ョンで1題の keynote paper と7題の paperがそれで れ発表された. keynote paper には討論時間を含め 45 分が，また他の paperには討論時間を含め 15 分が発表 洔間として与只られたこの発表に対する質疑応答はお 怙む权，時に演者が立ち往生させられる汪どの，活発 なものであった. keynote paper のタイトルと演者は， "Nutrient uptake by plants-Efficiency and control" (P.B. Tinker and R. A. Leigh, ローザムステット， 1 ギリス), "Agro-ecological considerations in the cultivation of perennial crops" (M. Z. Ghazali, マレーシ 


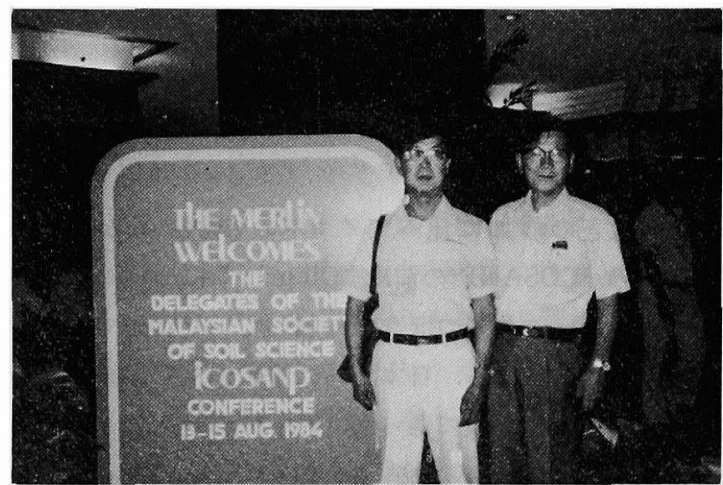

国際会議の会場, メルリン・ホテルのロビーで. 左, 筆者之, 右, 原田勇教授 (酪農学園大学).

ア農業研究所・マレーシア), および, “Maximizing the yields of perennial crops through integrated management" (K. M. Pretty and J. L. Sanders, カリ・リン酸 研究所, トロント, カナダ) であった. 発表された paper の国別の内訳は, マレーシア (13 題), 日本, スリ ランカ, 台湾 (各 3 題), インドネシア ( 2 題), シンガ ポール,フィージー島, パプア・ニューギニア, 中国, 西ドイッ,オランダ, ニュージーランド(各 1 題) であっ た.このらちニュージーランドの 1 題は, K. F. Kon ( マ レーシア) のニュージーランド留学中の仕事によるもの であり，日本からは I. Harada の “The relationships between selenium and sulphur in the alfalfa (Medicago sativa L.) and the orchardgrass (Dactylis glomelata L.) grown on different soils"(セッションI) と, 筆者の “Nitrogen levels and free amino acids in Morus alba roots from autumn through spring" $\varepsilon$ "Total nitrogen and purine alkaloids in Camellia sinensis throughout the year. Is caffeine a nitrogen storage compound in tea in winter?"(いすれれセッ ション UI）であった. また，扱われた永年作物は， oil palm ( 8 題), rubber ( 6 題), tea ( 4 題) のほかは, conifer, coconut, pineapple, citrus ponkan, cocoa, mulberry, orchardgrass, perennial pastures, sanifoin, asparagus の各 1 題であったが, oil palm やrubber plantation などの土壌の腐植酸やガス拡散などに関して 4 題ほど報告された.このように今回の会議はマレーシ アで開かれたこともあり熱帯永年作物が中心であった が, coffee や papaya, mungo などの熱帯果樹について の発表はなかった.このような永年作物に関する常設の 国際会議はあまり開かれていないと思うので直接の比较
は難しいが，木本永年作物では 1969 年にイギリスのブ りストル大学で “Physiology of Tree Crops” といら国 際シンポジウムが開かれている.そこでは appleなどの 果樹と conifer などの林木が主に扱われ，その他， tea， coffee, rubber, oil palm などであったので, 同じ永年 作物といっても開催地などによって著しく内容が違って くる.なお, rubber は依然としてマレーシアの最も主 要な作物であるが，最近のマレーシアの作付面積の伸び は oil palm のほらが著しく, 研究の主力もoil palm に 移っているようで, これが今回の ICOSANP の rubber と oil palm の発表件数の差として現れたよらであ る.

3 題の keynote paper と 31 題の研究発表をすべて聞 いたわけではないが, keynote paper については詳しく 紹介しなけれぱならないだろう。まず nutrition に関す るセッションの keynote paper では Tinker と Leigh が，植物栄養に関する研究の現段階について総括し，一 世紀にもわたる膨大な研究にもかかわらず大略しか明ら かにされていないことと，今後とくに解明されなければ ならない $5 つ の$ 基礎的な重要課題を指摘した. さらにこ のような状況にもかかわらず，作物栽培上実際に求めら れている課題にも答えなければならないといら practical な植物栄責研究の立場から，今回はとくに盖分吸収 の效率之制御に関する基礎研究のなかから批判的に選択 して, 実際上役に立ちそうだといら研究のいくつかの例 を紹介した，発展途上国で開かれる会議では生産性をあ げるという課題から実際的なものが多いが, Tinkerらの 植物栄養に関する基礎研究の重視と, 基礎研究を応用ま で展開させる姿梦, さらには植物栄養研究が今後詳しく 解明しなければならない 5 つ課題の提起には同感させ られるところ大であった。この nutrition に関するセッ ションでは, oil palm, rubber (各 2 題), 熱帯プランテ ーションの conifer, tea, citrus ponkan, cocoa, pineapple, orchardgrass, perennial pastures, sainfoin (各 1 題）の窒素, リン酸, カリ, イオウ, マグネシウム, マンガン，亜鈶などの養分吸収，欠乏症あるいは過剩症 などの問題が報告されたが, oil palm や coconutな どの palm trees では $\mathrm{Cl}^{-}$が生育をよく高めること と, それが孔辺細胞に澱粉を欠く植物では気孔の開閉に $\mathrm{Cl}^{-}$が関与していることが最近報告されているが palm trees にもよくあてはまるといらことによること (H. R. von Vexkull, シンガポール) や, 最近動物栄養や生化学 
から注目されているセレニウムの問題との関連から, alfalfa と orchardgrass の生育に対するイオウとセレニ ウムの拮抗的な影響に関する報告（I. Harada，日本）な どが與味深かった。

Plant and environment K関するセッションの keynote paper では M. Z. Ghazalli がまずマレー半島の気象 と土顀の特徵について述べ，その地域の特徽に応した永 年作物（rubber， oil palm，cocoa など）が载培されて いることを述べたが，日本列島の太平洋側と日本海側， また中央高地などに見られるような気象上の差異がマレ 一半島の東海岸側とマラッカ海陕側，また中央の山地な どに見られることとそれに応した土地利用の行われてい ることが興味深かった.このせッションでは, rubber ( 3 題), tea (2 題)のほか, oil palm, asparagusなどの 永年作物とともに, oil palm や coconut などのプラン テーションの土壤の, 腐植物質の変化と植物の生育に及 ぼす影響，ガス拡散などの問題が扱われた。筆者の tea と mulberry の窒素の年変動の窒素栄養と代謝に関する 報告以外は，いずれる熱帯あるいは無熱帯での永年作物 の生長と土壤に関するものであった，また，博友社から 翻訳が出版されている「中国土壤」の著者の 1 人である 刘崇群 (中国科学院南京土壤研究所副教授) は ${ }^{32} \mathrm{P}$ を使 った rubber の根からの盖分吸收之葉面散布について報 告したが，中国でも rubber が研究されていることを知 って興味深かった.これに対して，3回目の fertilizer use and management practices に関するセッションの keynote paper では, Pretty \& Sanders が，熱帯地力 における一年生作物之は違った永年作物の適切な栽培と 肥培管理の重要性について，それが增収ととも治質の 向上といら観点からも考虑されれなければならないことを 強調するとともに，その目的を達成するために注意しな ければならない事項のいくつか炍ついて指摘した。この セッションでは oil palm (5題)と rubber および tea (各1題)というょうに, oil palm の窒素, カリなどの 肥培管理に関するものが多かった。

これらの本会議のセッションに続いて，マレーシア土 较学会会長の Dr.M.C.Kim を議長として閉会のセッ ションが直らに行われた。 はずマレーシア・ゴム研究所 の生物学部門の副ディレタターで亦る Dr.E. Pushparajah が，報告された paper の個々について論評を加える とともに，会議の成果について概評した。これ続いて マレーシフ農業省の Y.B. Dr. Goh Cheng Teik の, 会
議の成果が実際面にもいかされることを強調する行政官 としての挨拶がありこの後最後の昼食が㘯って会議を 閉じた.このように会議は, keynote paper ではローザ ムステッドの Tinker らが植物栄養に関する基礎研究の 重要性を訴えたり，カリ・リン酸研究所のP Pretty らが 増収とともに品質向上をめざした肥培管理を強調するな どしたが，增收を目ざすための研究が一般的であり，

Dr. Teik の閉会の挨拶でも研究が永年作物の生産の增 大を図ることでマレーンフ農業の経済状況を改善するこ とが強調されるように，国の拁かれている立場について 考えさせられた。

先に紹介した「第 4 回ヨーロッパ植物生理学会連合会 議」とは異なり会期む短く, social events は8 月 14 日 の夕食会だけであった。しかしながら，この夕食会では 余興が準備されていなかったため参加者が「小話」を提 供することになりこれには原田先生御夫妻が先に退場 されていたため日本代表としては筆者の役割といらはめ になってしまった、しかしながら，筆者の英語力では 「小話」を話せるものではなく困ったが，筆者の前で西 ドイッの G. Kemmler がよく聞かされる話ではあるが 「日本人女性は従順で妻として最高である」旨の小話を したので，筆者はこれに反諭し，少なくとも若い世代は そらではないとのことで筆者の家庭を引き合いにして話 したところ意外に受けて役割を果たすことができた。 こ のように夕食会は和気あいあいとしたものとなった。

このよらに social events の少ない国際会議ではあっ たが通常ならばマレーシフ\$200ほどのホテルの部屋に マレーシア\$120で宿泊し快啇侗ごせたことや，会議 の休㥳時などに出された日本のらいるうに似たキャッサ バのでんぶんでできたというもち菓子と，夕暮れ時にホ テルから外出して sunday market の屋台で見た日本の みそ乱でんに似たマレーシフ風味のみそだ礼付きの拓で んに郷愁を覚えて，最も遠いイスラムの世界と考えてい たマレーシアという国に十分親近感を感じることができ た.さらら、この親近感は, post conference tour に参 加して，マレーシアの地方と人々，また緑豊かな自然に 触れることによりいっそう增したが，これらについては 他の機会に紹介したい。 また, post conference tour で はマレーシフはもちろん，とくにアジアの国々の研究者 と親しくなる貴重な機会る得たが，これについても他の 機会に紹介したい。

（京都工芸繊維大学 鈴木健夫） 